\title{
THE ECONOMIC IMPACT OF RENEWABLE AND NON-RENEWABLE ENERGY TECHNOLOGIES ON SMALL BUSINESSES: A CASE STUDY OF SMALL BUSINESSES NEAR THE WALLACEDENE TAXI RANK
}

\author{
Thembinkosi Maphosa', Abdullah Bayat ${ }^{2}$, Harold Annegarn ${ }^{3}$
}

\begin{abstract}
:
The South African National Development Plan contemplates that by 2030 the country will have an energy sector that promotes economic growth, development, social equity and environmental sustainability. This study explores the economic impact of renewable energy on the operations of small businesses located near the Wallacedene Taxi Rank. The taxi rank was built by the City of Cape Town as the first 'green' transport facility in South Africa. A self-administered questionnaire was used to survey a purposive sample of twenty (20) small business operators. Data analysis used descriptive statistics and content analysis. The key findings showed positive financial and operational benefits for small business operators using LPG gas stoves and solar-powered LED lights. There was evidence of positive correlation between the use of renewable energy and economic development at the micro- and macroeconomic levels. The study recommends the need for the government to proactively support the uptake, manufacturing and distribution of affordable renewable energy equipment. There is need to provide training and to upskill the labour force to gain employment in the renewable technology and related sectors.
\end{abstract}

Keywords: Clean cooking stoves, Economic impact, Manufacturing, Small business, Solar LED lighting

\section{Introduction}

Energy plays a crucial role in almost every production process and in the fulfillment of personal and business needs (OECD, 2011). Energy-driven economic growth refers to the process that seeks to increase energy efficiency and/or diversification of energy resources that would create new jobs, maintain employment, and encourage the prosperity of regions (Carley, et al, 2011). Maradin et al (2017 p.6) highlight the concept of energy-driven economic growth and its focus on fulfilling economic and energy development needs. Smith (2017, p. 6) and Maradin et al (2017 p.6) outline the key objectives as follows: increasing energy efficiency, diversification of resources, self-sufficiency, improvement of industry and economic growth, entrepreneurship, technological innovation, higher employment levels, and enhancing opportunities for training opportunities. Developing countries like South Africa that are characterized by rising electricity prices, will greatly benefit from investments in renewable energy technologies and the introduction of independent power producers (IRENA, 2016). Samouilids and Mitropoulos (1982), Nakata (2004) and Maradin et al (2017) have highlighted the impact of energy on the economic growth.

1University of the Western Cape; tmaphosa@uwc.ac.za

2University of the Western Cape; abbayat@uwc.ac.za

${ }^{3}$ North-West University; hannegarn@gmail.com 
This study examines the economic influence of solar LED light and LPG stoves on small businesses in Wallacedene, Kraaifontein in Cape Town. The central research question examines a) the economic impact of introducing renewable energy technologies (thereafter RETs), such as solar LED lighting and LPG stoves to complement nonrenewable energy technologies (thereafter, NRETs) on small businesses in low income communities, and b) the impact of renewable energy technologies on the energy manufacturing industry.

\section{Background}

The Wallacedene taxi rank was built by the City of Cape Town in South Africa, as the first 'green' transport facility in South Africa (Petterson, 2014). The taxi rank was unveiled on Monday 25 August 2014 (Meiring, 2014). The public transport facility generates its own electricity, enabling it to operate off the electricity grid (Green Africa Directory, 2015). It serves approximately 5000 commuters daily. The development of the taxi rank has attracted small businesses operating within a 200 meters radius, and that started using LPG gas cooking stoves and solar powered LED lights.

\section{Literature review}

Economic impact can be defined as the effects of levels of economic activity in a given area (Weisbrod and Weisbrod, 1997, p. 1). The authors point out that the indicators of economic impact include business output or sales volume; value added or gross regional product; wealth creation inclusive of property values; personal income and job creation. Energy-driven economic growth is characterized by integrated planning to ensure future energy security, stability, and high customer demand. as well as investments in the manufacturing of renewable energy technologies. Subsequent increases in energy efficiency and/or diversification of energy resources enhance the creation of new jobs, maintaining employment, and it encourages prosperity within the respective national regions (Carley, et al, 2011, p. 283). Maradin et al (2017 p.6) reiterate the concept of energy-driven economic growth towards fulfilling economic and energy development needs. Smith $(2017$, p. 6) and Maradin et al (2017 p.6) note that the key objective is aimed at increasing energy efficiency, diversification of resources, self-sufficiency, industry, economic growth and entrepreneurship, technological innovation, employment creation and opportunities for training and development. Nanda (2015) cited in Maradin et al (2017 p.2) pointed out the direct relationship between investments in the renewable energy sector and the stimulation of capital flows through the economy. They also highlighted the direct and indirect expansion in related sectors that promotes employment levels within the renewable energy sector.

\section{Renewable energy technologies (RETs) and non-renewable technologies (NRETs)}

Pollution emitted through use of coal by small braai businesses in low income communities poses several health and environmental hazards (Maradin et al, 2017). They produce $\mathrm{CO}_{2}$ emissions which contribute to global warming and climate change (IPCC, 2017). Renewable energy technologies such as solar LED lights and LPG stoves reduce greenhouse gas emissions, as well as stabilize energy prices and generate economic benefits (IPCC, 2017). Mohlakoana, and Annecke (2008) reported that the majority of residents and business operators in low-income communities rely on 'dirty' fuels such as firewood, coal and parafin. These fuels account for deadly hazards such as air pollution and fire hazards.

Energy interventions using LPG gas improve the quality of life and business operations when compared to traditonal fuels. LPG gas is economical as "one pays for what they use, there is no loss of heat unlike with other fuels" (Mohlakoana, and Annecke, 2008, p. 5). Integrated Energy Solutions (IES, 2007) cited in Mohlakoana and Annecke (2008 p. 5), highlights the benefits of cooking with LPG gas for households:

- Gas is an acclaimed and preferred cooking fuel internationally;

- Gas is clean, controllable, fast and efficient;

- The hob-heating settings on gas appliances are more precise, compared to low standard electrical hobs;

- Gas is safe and has an international safety record, unlike electricity and other commercial energy sources;

- It is portable and can be stored safely; and

- Gas appliances generally last longer if used correctly.

Picture 1 below illustrate the transition from coal-fired cooking to LPG gas. 


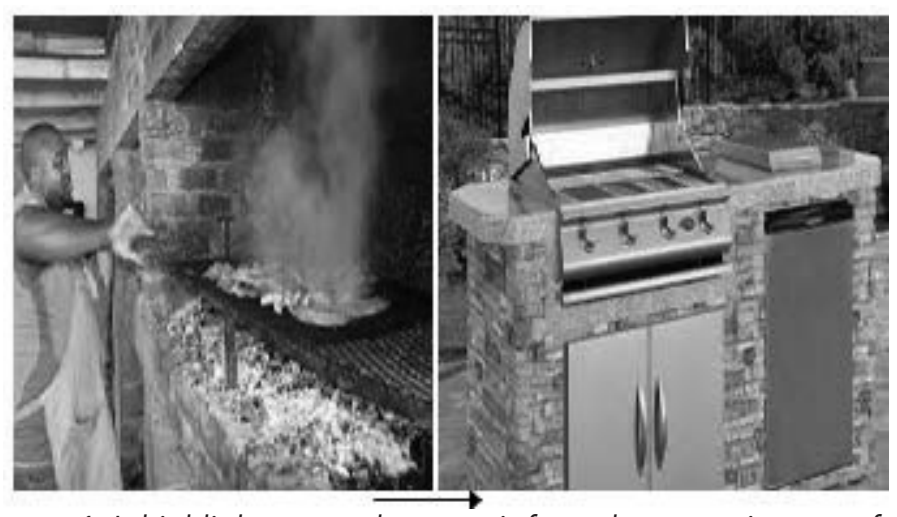

Picture 1: It highlights a need to transit from the excessive use of coal, to $L P G$ for braai activities, for example.

Picture 2 below shows incandescent lights and solar LED lights.

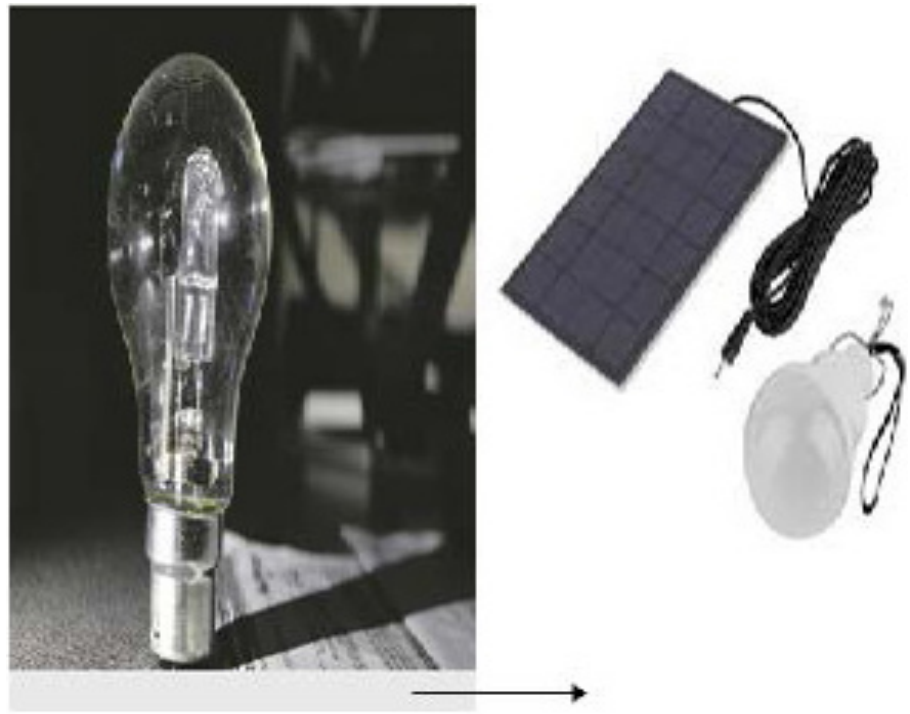

Picture 2: Shows the solar LED lights which can replace the incandescent light bulb

Hacker (2016) points out that solar LED lights possess six (6) major energy saving benefits for businesses compared to incandescent lights:

- Reduce energy consumption and costs (they use only about a tenth of the energy of incandescent lights, resulting in huge savings in utility bills over time);

- Long-lasting product (average incandescent bulb lasts for about 1000 hours, whilst LED light lasts between 25000 to 50000 hours);

- Convenience (E.g. for the replacement of 25-50 incandescent lights, one LED light would have been replaced);

- Quality of light (provide more focused lighting that is perfect for everything from desk to showroom lighting);

- No heat, noise, or emissions (incandescent lights can get hot, and a certain type of light produce UV emissions); and

- Recycling options (incandescent bulbs contain toxic mercury that is unsuitable for recycling, compared to LEDs which can be recycled at the end of their lifetime).

\section{Employment creation}

Investments in solar LED lights and LPG stoves have contributed to the reduction in climate change (Omri et al., 2015p.61), as well as to the growth in the demand for renewable and progressive decreases in the costs of renewable energy, and the creation of new employment opportunities. Maphosa et al., (2018) pointed out that the development of the renewable energy market had been a significant contributor to employment creation. The global renewable energy sector grew by $5 \%$ annually and contributed to the direct and indirect employment of 8.1 million people by 2015 (IRENA, 2016). Over the same period, the solar photovoltaic industry accounted 
for 2.8 million jobs globally, with the wind power sector recording yearly growth rates. Maradin et al (2017 p.51) estimated that the renewable energy sector in the EU will account for over 900,000 new jobs by 2020, as well as 515,000 jobs in agriculture and the biomass fuel supply chain. A growing number of countries are achieving high employment levels from renewable energy activities, especially in the LPG energy industry (Ecotec, 2002). Asu (2017) highlights that given the appropriate government policies, the renewable energy sector will create new jobs through investments in local manufacturing of gas cylinders, retail, autogas and power generation services. Asu (2017) reported that Nigeria had established three-hundred (300) LPG distribution points retailing 500000 tonnes of cooking gas. The Nigerian Federal Government Draft National Gas Policy has allocated US $\$ 10.38$ bn towards the generation of renewable energy, in the quest to reduce dependence on kerosene and firewood by $50 \%$ by 2018 (Asu,2017). The investment is estimated to create one million skilled jobs in various segments of the Nigerian LPG supply value chain.

\section{The Energy-economy model: the conceptual framework}

This study developed and adapted a conceptual framework from the the Energy-economy model by Samouilidis and Mitropoulos (1982). This study adopts the model that is applied to assess the relationship between energy initiatives and the economy (see Figure 1 below). The framework offers some theoretical propositions for understanding the interaction and synergies between energy activities and the economy.

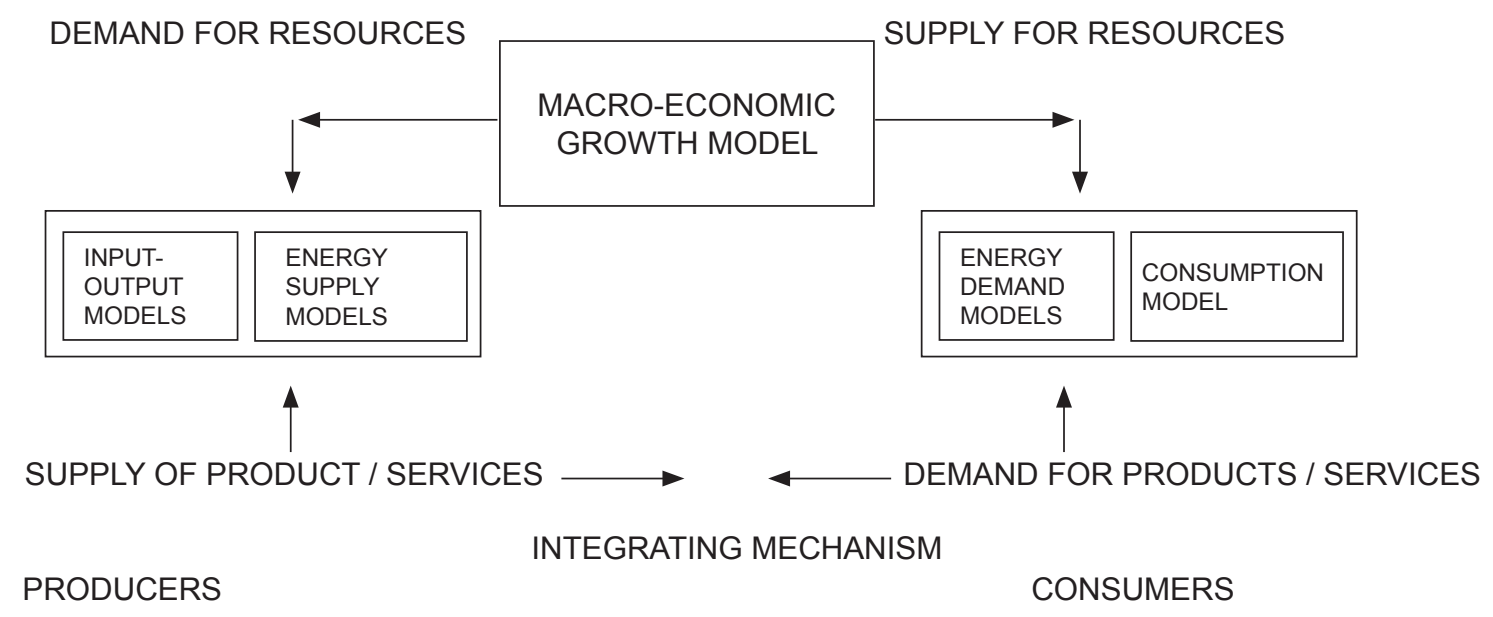

Source: Samouilidis and Mitropoulos (1982) in Maradin et al (2017 p.52)

Figure 1: The energy-economy Model

The underlying approach of the model asserts that an energy system does not exist 'for itself', and should be viewed in the context of the entire economic system. Thus, the energy ecosystem is observed as an anchor for the economy, because of the manufacturing of energy-related products such as gas cylinders, solar LED lights and the provision of services. Thus the energy ecosystem becomes a key driver of broader economic processes. There is a growing body of empirical studies supporting the positive impact of energy systems on the economy (e.g. Energy Modeling Forum, 1977; Manne, Richels, and Weyant, 1979; Ormerod, 1980; Kavrakoglu 1987; DeCarolis, Hunter, and Sreepathi, 2012). This is supported by energy-economy-environmental models (eg., Nakata, 2004; Dong et al, 2014). The energy-economy model by Samouilidis and Mitropoulos (1982) emphasizes the significance of the interaction between the supply side and demand side of the energy sector, as well as the impact on the broader economic subsectors. Nakata (2004) points out that the energy-economic model demonstrates the dynamics within an economic system. 
The propositions by Samouilidis and Mitropoulos (1982); Nakata, (2004) and Maradin, et al (2017) on macroeconomic growth models, comprise the following elements: input-output (or supply) models and energy-supply models for producers, and consumption models and energy demand models for consumers. In many ways the macroeconomic growth model depicts the classical notion of economic equilibrium where supply = demand. Jaccard (2015) argues that input-output models represent inter-sectorial flows and the behavioural patterns of the producers. The energy supply models analyze the impact of new technologies and the optimal structure of the energy system, and prove an important starting point in generating energy-driven economic growth (Luis, and Neij,(2009). In contrast, the demand side of the consumption models investigate consumers' behavioural patterns in terms of aggregate demand for products and services (Maradin et al., 2017 p. 53). Nakata (2004) emphasizes that energy demand models assess price effects, tax and tariff effects, energy conservation and energy efficiency.

There are few empirical studies that investigate the interaction between energy and economy, with specific reference to small business organisations within the context of a developing country. This study contributes to studies on the energy-economy interaction at the micro-level, primarily small businesses operating within low income communities. The main research aim is to investigate the energy ecosystem comprising LPG stoves and solar LED lights and the impact it has on the operations and viability of the small business sector.

\section{Methodology}

The study adopted a survey design to investigate the economic impact of renewable energy on the small business sector in Cape Town, South Africa. Data collection used self-completed questionnaires and an interview schedule. A pilot study was used to test the validity and reliability of the data collection instruments, and appropriate changes were made. The study population comprised all small business operators at the Wallacedene Taxi Rank. A simple random sampling technique was used to select business operators who participated in the study. Simple random sampling is a type of probability sampling (Crossman, 2018). Kalton (2011) notes that the sample size is $n$ and the population size is $\mathrm{N}$, where $\mathrm{N}$ represents approximately fifty $(50)$ small businesses, the majority of which were not registered with the Kraaifontein Municipality. The study sample comprise twenty (20) small businesses operating within a $200 \mathrm{~m}$ radius from the Wallacedene Taxi Rank. Purposive sampling is a type of non-probability sampling and elements selected for sampling are regarded as experts based on the researchers' judgement (Dudovskiy, 2018; Lavrakas, 2008). The researchers used their judgement in selecting energy-economy experts who participated in the study.

Data analysis used descriptive statistics and content analysis.

\section{Findings}

Table 1: Ownership of LED lights

\begin{tabular}{|l|l|l|}
\hline $\begin{array}{l}\text { Have a Solar LED } \\
\text { Light }\end{array}$ & $\begin{array}{l}\text { Response } \\
\text { (Number) }\end{array}$ & $\begin{array}{l}\text { Response } \\
(\%)\end{array}$ \\
\hline Yes & 3 & 15 \\
\hline No & 17 & 85 \\
\hline Total & 20 & 100 \\
\hline
\end{tabular}

Table 1 above shows that $15 \%$ of the business operators owned and used LED lights in their business operations. While the majority (85\%) reported that they did not own nor use LED lights. This supports observations by Hacker (2016) that the majority of the small business operators - mostly operating small spaza tuck-shops - do not own nor use solar-powered LED lights. 
Table 2: Users of LPG stove for preparing meals for customers

\begin{tabular}{|l|l|l|}
\hline Use of LPG stove & $\begin{array}{l}\text { Response } \\
\text { (Number) }\end{array}$ & $\begin{array}{l}\text { Response } \\
(\%)\end{array}$ \\
\hline Yes & 12 & 60 \\
\hline No & 8 & 40 \\
\hline Total & 20 & 100 \\
\hline
\end{tabular}

Table 2 above shows that the majority (60\%) of the operators used LPG stoves to prepare food sold to clients. While $40 \%$ of the respondents in the business of selling cooked food did not use LPG stoves for preparing meals for their customers. This supports observations by Mohlakoana et al (2009).

\section{The demand side: use of solar LED lights and LPG stoves}

The majority of the respondents (60\%) reported increases in business profits and efficiencies in operational processes, as a result of using solar-powered LPG stoves. More importantly, the respondents reported that they were now able to remain open for longer business hours after they started using affordable energy. Respondents cooking meals such as Chisa Nyama, reported that they were realizing higher profit margins after switching from conventional electricity to renewable energy sources. The OECD (2011a) pointed out that investments and the application of renewable energy technologies contribute to significant economic growth and development. Investments in renewable energy contribute towards the creation of sustainable 'green' economies (Energy Modeling Forum 977; Manne et al (1979); Ormerod, 1980; Kavrakoglu 1987; DeCarolis, Hunter, and Sreepathi, 2012).Nakata, 2004; Dong et al, (2014) and Samouilidis and Mitropoulos (1982).

Most of the respondents cited benefits of using renewable energy, such as opening for longer business hours and subsequent higher profit margins. Thus RETs enhance the development and revitalization of local economies (IEA, RETD TCP, 2016). The study findings support the propositions of the energy-economy model (Samouilidis and Mitropoulos, 1982) and its predictions for the creation of new business opportunities and higher employment levels.

\section{The supply side: use of solar LED lights and LPG stoves}

The study findings showed financial benefits (Table 2 above) arising from using RETs, as well as the environmental implications arising from the reduction of fossil fuels at the macro-environmental level. The shift towards the use of renewable energy at the micro-environmental level will gradually reduce energy costs. This increases the demand for sustainable RETs such as LPG stoves, thereby reducing pollution and emission of greenhouse gases. It also enhances the creation of new investments in RETs as well as employment opportunities. In the United Nations Kyoto Clean Development Mechanisms and the White Paper on Energy Policy - South Africa $(1998 ; 2012)$ emphasize the need to reduce the impact on climate change through diversification into renewable energy.

Table 3 summarises the advantages and disadvantages of using solar LED lighting and LPG stoves in small businesses in low income communities. 
Table 3: Depicting the advantages and disadvantages of using solar LED lighting and LPG stoves.

\begin{tabular}{|c|c|c|}
\hline Advantages at a Macroscale & $\begin{array}{l}\text { Advantages to the small business } \\
\text { operator }\end{array}$ & Overall disadvantage \\
\hline 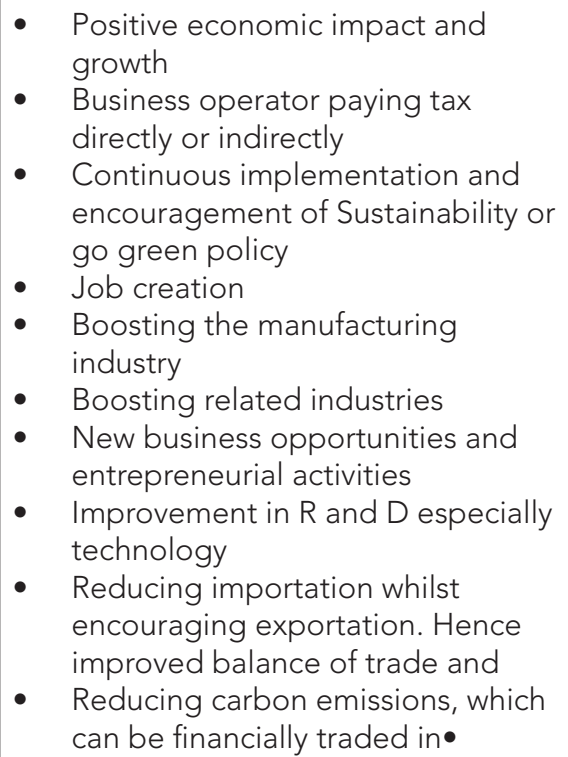 & 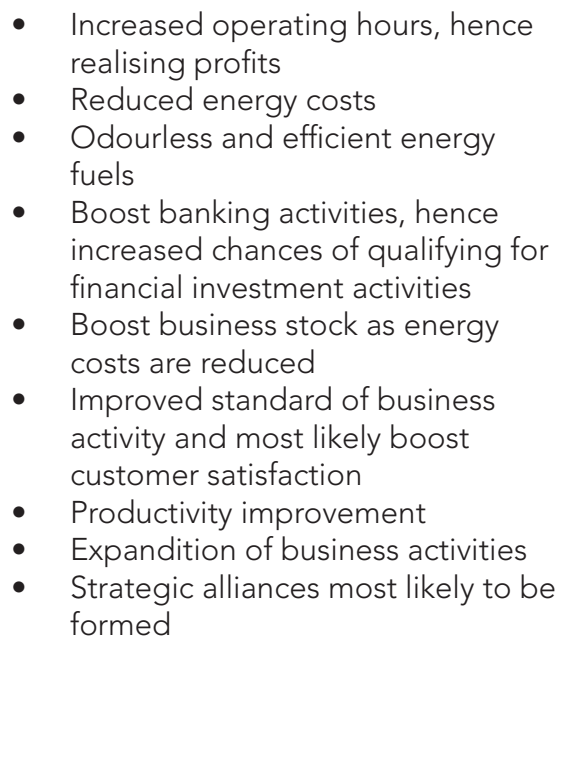 & $\begin{array}{l}\text { - } \quad \text { relatively high initial cost of } \\
\text { purchasing the RETs } \\
\text { Acceptability of the LPG as } \\
\text { most operators might view it as } \\
\text { dangerous. This limitation can } \\
\text { be reduced through extensive } \\
\text { education on how to use these } \\
\text { technologies } \\
\text { - Reliability of energy supply }\end{array}$ \\
\hline
\end{tabular}

Source: Authors

\section{Discussion}

The study findings show that there is a direct relationship between the use of renewable energy technologies (solar LED lighting and LPG stoves) and the financial benefits of small business operators in Wallacedene, Kraaifontein in Cape Town. The findings support Maradin et al (2017 p.50) on the competitiveness of renewable energy sources compared to non-renewables, like electricity generated by hydropower and fossil fuels, as well as on the benefits of unlocking affordable off-grid energy for low income communities.

The second research objective was to assess the implications of renewable energy and non-renewable energy technologies on the energy manufacturing industry. The study findings observed operational benefits for small business operators, and these generate a demand for renewable energy equipment and accessories. This resonates with observations by Maradin et al (2016 p. 54) on the viability of an energy-based economic development drive, which integrates economic development, energy policy and planning into the management of national economies. The study supports propositions of the energy-economic model (Samouilidis and Mitropoulos, 1982). The results of the study concur with the observations by South African manufacturing companies for solar LED lighting on the critical role of the renewable energy sector on economic developments. The demand for renewable energy enhances investments in the improvement of renewable energy technologies. The manufacturing and distribution of RETs stimulate the growth of the steel industry, research institutions, and related industry sectors.

Notwithstanding the observations by Maradin, et al., (2017, p. 55) on the high initial capital costs and low deployment rates of renewable energy, the challenges for a developing country like South Africa is the availablity of funds to develop the RETs industry and market. Goldman, (2010) highlights challenges encountered in the installation of solar water heaters in the Kuyasa community of Khayelitsha township, using kits manufactured in China and which benefited the Chinese economy more than the South African economy. However, South African companies continue to develop a manufacturing capacity, evidenced by their combined role in supplying 2309 RDP houses in Kuyasa with solar water heaters (BHCP, GBC, 2012). In addition, a 1000 solar water heaters were supplied by Hotmix (Pty) Ltd, a South African geyser manufacturing company. 


\section{Conclusions}

The study findings showed that small business operators benefited financially and were able to improve operational efficiencies through using renewable energy-driven LED lights and LPG stoves. Further, the study observed the potential economic benefits of reneweable energy equipment and accessories for users (demand side) and manufacturers (supply side). The study recommends government interventions and support through providing incentives and rebates for the manufacturing and distribution of renewable energy equipment. These efforts will greatly benefit the small business sector and the larger economy. There is need to provide training and development for the labour force to enhance employability in the renewable technology and related sectors.

The study was based on a single site in Cape Town. There is need for further studies using different methologies to investigate the impact of renewable energy on small businesses in other sectors and regions of South Africa.

\section{Bibliography}

Asu, F. (Februaury 2, 2017). LPG market can create two million jobs. Punch.

BHCP, GBC. (2012). Improving lives by greening low cost housing: Case study report of the Cato Manor Green Street retrofit. Pretoria, South Africa: Green Building Council of South Africa, British High Commission Pretoria.

Carley, S. et al. (2011). Energy-based economic development. Renewable and Sustainable Energy Reviews, 15 (1), 282-295.

Cilliers, H. (2015, October 19). Electricity or gas: how to choose. Retrieved July 11, 2018, from https://www. moneyweb.co.za/news/South-Africa/electricity-or-gas-how-to-choose

Crossman, A. (2018, January 13). Simple Random Sampling. Retrieved June 13, 2018, from Definition and Different Approaches: https://www.thoughtco.com/random-sampling

DoBE. (2017). National School Nutrition Programme - Gas Safety in Schools. Department of Basic Education. Pretoria, South Africa: DoBE.

Dudovskiy, J. (2018). Research Methodology : Purposive Sampling. Retrieved from The Ultimate Guide to Writing a Dissertation, In Business Studies- A step-by-step assistance: http://www.research-methodology.net

GIG. (2018, July 9). Give it Gas. Retrieved from http://www.giveitgas.co.za

Goldman, M. (2010). Kuyasa CDM Project: Renewable Energy Efficient Technology for the Poor. Cape Town, South Africa: SouthSouthNorth.

Green Africa Directory. (2015). City of Cape Town Opens Green Taxi rank in Nomzamo. Cape Town: Green economy, Green lifestyle, building and design, Green travel and tourism.

Hacker, T. (2016). 6 major benefits of LED lighting for your benefits. Indianapolis: Fixtures for lighting.

IEA, RETD TCP. (2016). Renewable Energy Medium-Term Market Report, 2016 : Market Analysis and Forecasts to 2021. Paris, France: International Energy Agency.

International Energy Agency. Photovoltaic Power Systems Programme. (2017). Retrieved May 29, 2018, from International Energy Agency. Photovoltaic Power Systems Programme: http://www.iea-pvps.org/index.php?id=32

IRENA. (2016). International Renewable Energy Agency-RoadMap for a Renewable Energy Future. Abu Dhabi.

Jaccard, M. (2015, April ). Energy-economy modeling and behavioral realism : How much is useful? Simon Fraser University.

Jeremiah, M. (2018). Small holder farmers. ZFU, 3-9.

Kabir, E, Kim, K and Szulejko, J. (2017, October 16). Social Impacts of Solar Home Systems in Rural Areas: A case study in Bangladesh. MDPI energies.

Kalton, G. (2011). Simple Random Sampling in Introduction to Survey Sampling. SAGE Publications, 1-8.

Lavrakas, P.J. (2008). Purposive Sample. In: Encyclopedia of survey research methods. SAGE publications, 1-3. 
Luis, M and Neij, L. (2009). Energy-economy models and energy efficiency policy evaluation for the household sector. Lundi University. The International Institute of Industrial Environmental Economics.

Maphosa, T; Bayat, A and Lloyd, J, P. (2018). The entrepreneurship ventures from former participants in the Kuyasa Clean Development Mechanism renewable energy project. IPASJ International Journal of Management (IIJM), 6 (4), 5-18.

Maradin, D; Cerovic, L and Mjeda, T. (2017). Economic Effects of Renewable Energy Technology. Nase gaspodarstvo / Our Economy, 49-59.

Meiring, B.L. (2014, August 25). VISI South Africa's Most Beautiful Magazine - Architecture. Retrieved July 10, 2018, from South Africa's First Green Taxi Rank: https://www.visi.co.za/South-Africas-first-green-taxi-rank

Mohlakoana, N and Annecke, W. (2008). Finally Breaking the barriers: South Africa Case Study on LPG use by lowincome urban households. Istanbul Pre-conference workshop on "clean cooking fuels" .

Mohlakoana, N and Annecke, W. (2009). The use of liquefied petroleum gas by South African Low-income urban households: A case study. Journal of Energy in Southern Africa, 20 (4).

Nakata,T. (2004). Energy-economic models and the environment. Progress in Energy and Combustion Science, 30 (4).

OECD. (2011). Joint report by IEA, OPEC, OECD and World Bank on fossil-fuel and other energy subsidies: An update of the G20 Pittsburgh and Toronto Commitments. Paris: World Bank.

Omri, E; Chtourou, N and Bazin, D. (2015). Rethinking the green recovery through renewable energy expansion. International Journal of Sustainable Development, 18 (1/2), 59-76.

Petterson, D. (2014, August 26). South Africa's first green taxi rank. Retrieved May 31, 2018, from Infrastructure news and service delivery: http://www.infrastructurene.ws and service delivery

Samouilidis, J.E and Mitropoulos, C.S. (1982). Energy-Economy models: A survey. European Journal of Operational Research, 11 (3), 222-232.

Smith, R. (2017). Regional Economic Impact of BWI Marshall Airport. Washington: Baltimore / Washington International Thurgood Marshall Airport.

Weisbrod, G and Weisbrod, B. (1997). Measuring economic impacts of projects and programs. Economic Development Research Group, 1-11.

World Bank. (2012). The World Bank Annual Report 2012. Washington D.C: Main Report. World Bank Annual Report. 